\title{
The Oceans as Educational Philosophy
}

John A. Knauss

University of Rhode Island - Narragansett, Rhode Island USA

I believe a strong case can be made that publication of The Oceans: Their Physics, Chemistry, and Biology (Sverdrup, Johnson, and Fleming, 1942) was the most influential contribution-perhaps the most important contribution - of Scripps Institution of Oceanography's first half century. This thousand-plus page book by Scripps Director Harald U. Sverdrup and two junior members of the faculty, Richard Fleming and Martin Johnson, set the tone for how oceanography was to be taught in the United States. First published in 1942, the book remained in print until 1985 . There never was a second edition. The book's publishing company, Prentice Hall, apparently has no way of determining how many copies were sold during this 43 -year period (Lynch, 2003).

\section{The Sverdrup Curriculum}

Advanced degrees in earth sciences, especially geology, have been offered in this country since the early nineteenth century, but oceanography is a twentieth-century discipline. At Scripps, and I expect elsewhere, the earliest degrees carried a qualifying adjective such as chemical oceanography or biological oceanography. The first unqualified oceanography degrees from Scripps were awarded in 1935 and 1936 to Fleming and to Roger Revelle (Raitt and Moulton, 1967), but I believe it is fair to say that formal education in oceanography at Scripps did not take off until the closing days of World War II. I use the term take off advisedly. There were only 30 Scripps Ph.D. oceanography graduates in the first postwar decade, 1947-1956 (Raitt and Moulton, 1967).

The Oceans attempted, with considerable success I believe, to integrate in a single text the essentials of what was known about the oceans prior to World War II-the physics, chemistry, biology, and geology of the seafloor. The postwar Scripps educational program was also designed by Sverdrup, and, like The Oceans, it attempted to cover all bases through formal course requirements. All students were required to take four introductory courses: physical oceanography, chemical oceanography, biological oceanography, and geological oceanography. For a number of years, the so-called "departmental exam," the first of the two general exams for all Ph.D. students, and the primary exam for those earning a masters degree, was based on those four courses.

As part of this Scripps 100-year-birthday celebration, I have attempted to determine how wide spread the Sverdup-Scripps educational model was and the extent to which it is still followed. The short answer is that the Sverdrup-Scripps model was adopted by almost all of the new post-World War II oceanography programs. With few exceptions, this model is still being followed.

Using the Consortium for Oceanographic Research and Education (CORE) membership list, I sent a brief questionnaire to each member institution inquiring about its educational history and philosophy. Nearly 80 percent responded, and the responders are listed in Table 1 by date of educational program inception. In some cases, choosing the date was not simple. For such programs as those at Texas A\&M University and Oregon State University, the beginning date is clear. There were no programs until Dale Leipper and Wayne Burt, respectively, showed up to start them. At other schools such as the University of Washington and the University of Rhode Island, full-fledged oceanography programs were built on already existing marine programs, an interdepartmental effort started some years before World War II at Washington, and a small free standing biological oceanography program was imbedded within the Department of Zoology at Rhode Island. For one of the largest programs, Woods Hole Oceanographic Institution, the start date is easy. Although Woods Hole began operation in 1930, its formal educational program began as a joint Woods Hole-Massachusetts Institute of Technology program in 1968. The University of Alaska and University of California, Santa Barbara (UCSB) dates are more complicated. Both offered marine-oriented degrees through a number of traditional departments for many years, but a formal interdepartmental program in marine sciences did not begin until 1970 for Alaska and 1997 for UCSB.

As its original name suggests, the Lamont Geological Observatory under Maurice Ewing began not as a program in oceanography, but in marine geology and geophysics. Under Ewing's leadership, and those that have followed, its range of activities has grown, and the name of the institution has changed to 


\section{Table 1.}

Graduate oceanography programs in the United States, by date of origin

Year University

1949 University of Miami

1949 Texas A\&M University

1951 University of Washington

1954 Oregon State University

1960 Lovisiana State University

1960 University of Alaska

1962 University of Rhode Island

1964 Virginia Institute of Marine Science

1964 University of Hawaii

1966 Old Dominion University

1966 Moss Landing (California State Colleges)

1966 Nova University

1967 University of South Florida

1967 University of North Carolina, Chapel Hill

1968 Woods Hole Oceanographic Institution

1970 University of Delaware

1972 University of South Carolina

1977 University of Maryland

1978 University of New York, Stoney Brook

1981 University of North Carolina, Wilmington

1981 University of California, Santa Cruz

1994 Rutgers University

1997 University of California, Santa Barbara

reflect these broadening interests: Lamont-Doherty Earth Observatory. However, Lamont still does not offer a degree in oceanography, and paleontology is the closest to biology one can find among either the faculty or the curricula. Thus, I did not include Lamont in this survey.

\section{Scripps Breeds New Oceanography Programs}

Scripps graduates played a major role in the development of many of the early oceanography programs. Of the eight that were in place by 1965, five were initiated by Scripps graduates. Leipper started the program at Texas A\&M in 1949; Fleming, one of the three authors of The Oceans, became the first chairman of the new department of oceanography at the University of

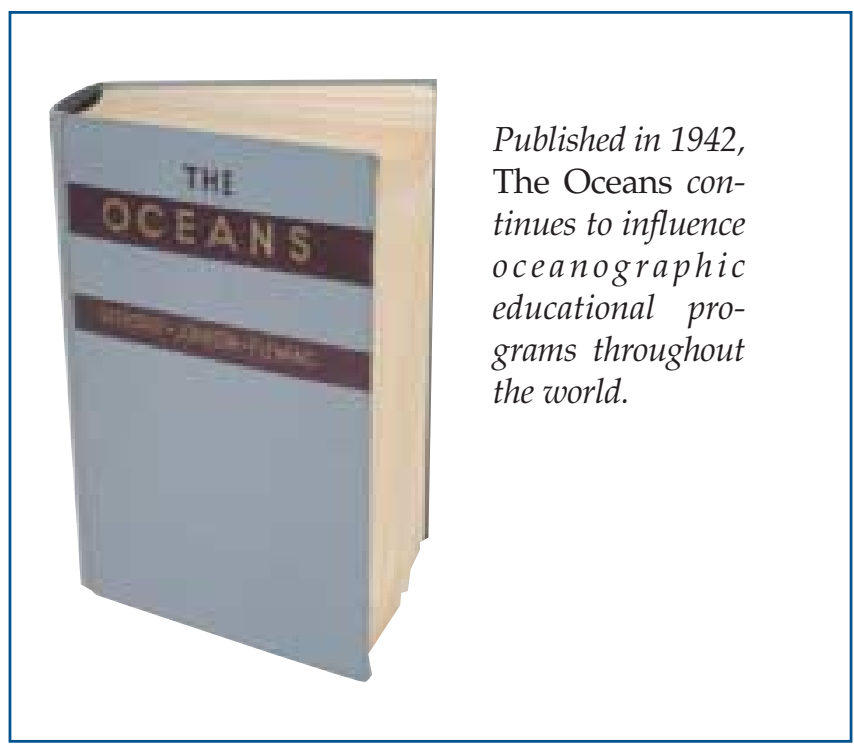

Washington in 1951; Burt began the program at Oregon State in 1959; I started the program at the University of Rhode Island in 1962; and Lawrence McHugh started the program at Virginia Institute of Marine Science in 1963. We each carried the Sverdrup educational philosophy with us, requiring all students to take the four basic courses in oceanography as we had been required to do while at Scripps.

Perhaps because of the dominant educational role of Scripps, particularly before Woods Hole began its degree-granting program, and perhaps in part because of the four "missionaries" who founded the programs, all programs listed in Table 1, with just one exception, adopted the Scripps four course sequence, or a reasonably close approximation thereof. However, it did not happen at the University of Miami until 1973 when Warren Wooster, an early Scripps graduate, succeeded the program's founder, F.G. Walton Smith.

The exception, and it is a big one, is Woods Hole. It did not adopt the Sverdrup-Scripps model when it began its educational program in 1968, but I note that it has slowly evolved in recent years to a reasonable facsimile. All but the physical oceanography students now take from one to three so-called core courses outside of their discipline.

\section{The Legacy of The Oceans}

Our knowledge of the ocean has grown significantly in the last half century. Although much of basic oceanography was encapsulated in The Oceans in 1942, one need only peruse the abstracts of the oceans section of the American Geophysical Union (AGU) over the last 20 years or attend the biannual meetings of the AGU and the American Society of Limnology and Oceanography to see how varied and complex our field has become. And some would argue that there is now a fifth discipline-meteorology-with which oceanographers should have some familiarity. 


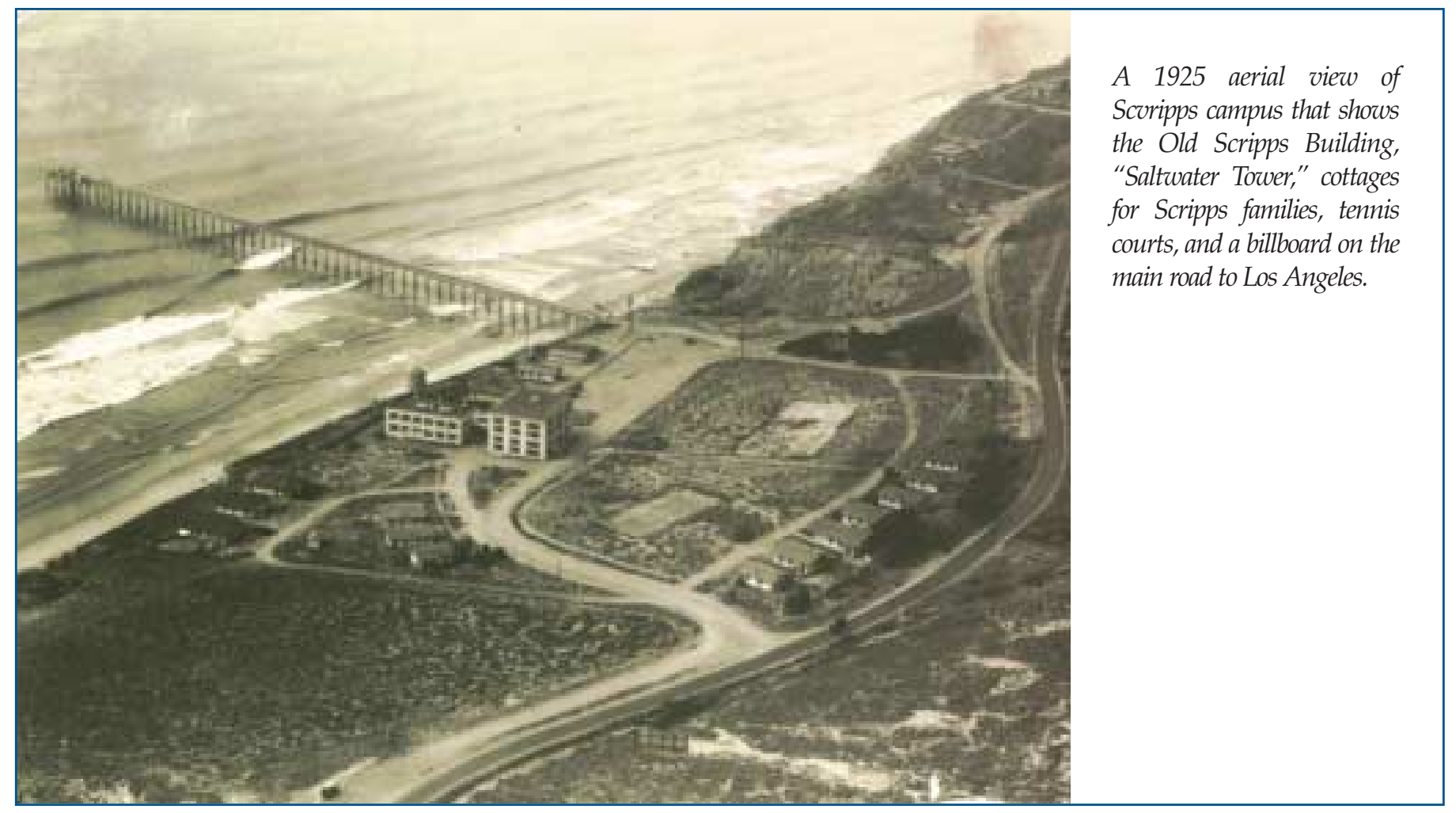

One consequence of this growth is renewed discussion of what should constitute the core requirements for breadth of knowledge in oceanography. However, of the twenty-four programs listed in Table 1 , only two have significantly modified their original requirements. At the University of Rhode Island those students specializing in biological and chemical oceanography continue to take the four basic courses. If you are a geologist or geophysicist, the requirement is only two of the three in addition to geological oceanography; for physical oceanographers, the requirement is only one of the three in addition to physical oceanography. The University of Miami now requires its students to take only one of the four courses outside of their major. A few of the newer programs have never required all students to take courses in all four disciplines. For example, at Rutgers University all students must take three of the four classes including physical oceanography.

Perhaps the institution that has strayed furthest from the Sverdrup path is Scripps, the birthplace of the Sverdrup model. The requirement that all students take basic courses in the four disciplines of oceanography began to break down in the early 1960s, about the time many of the new oceanography programs were becoming established at other institutions and were adopting the Sverdrup philosophy. However, the pendulum may be swinging back. In response to the questionnaire I sent to all oceanographic institutions, Scripps Director Charles F. Kennel included the following note: "The idea that all students should take a common breadth curriculum is however regaining ground" (Kennel, 2002).
Our knowledge base of the oceans has exploded since Sverdrup, Johnson, and Fleming completed their magnum opus. The most recent attempt to emulate The Oceans covers 3,000 pages in six volumes: Encyclopedia of Ocean Sciences (Steele et al., 2001). Perhaps the intellectual range of what is encompassed by what we now accept as oceanography is so challenging that it is no longer reasonable to expect all of our students to have at least some level of understanding of the entire field, but I am not convinced. I believe there is still a place for Sverdrup's view of the oceans and what it means to be an oceanographer.

\section{References}

Kennel, C., 2002: personal communication, October 18, 2002.

Lynch, P., 2003: personal communication, Prentice Hall, ed., January 7, 2003.

Raitt, H. and B. Moulton, 1967: Scripps Institution of Oceanography. The Ward RichiePress, Los Angeles, 217 pp.

Steele, J.H., K.K. Turekian and S.A. Thorpe, 2001: Encyclopedia of Ocean Sciences. Academic Press, San Diego, California, 3000 pp.

Sverdrup, H., M. Johnson, and R. Fleming, 1942: The Oceans: Their Physics, Chemistry, and Biology. Prentice Hall, New York, 1060 pp. 